nevertheless be employed as a check upon herpetological systems. The classification of Duméril and Bibron, founded essentially upon the dentition, establishes groups which by no means coincide with the absence, presence, or number of pits on the scales. M. Reinhardt considers this classification as essentially artificial. He admits that within certain limits the dentition has an incontestable systematic importance, but he does not think that it can be regarded as a character ruling all others. All the attempts hitherto made at classifying Serpents in accordance with the dentition alone have led to the approximation of very diverse species, and to the separation of allied forms. On the other hand, M. Reinhardt considers the groups established by Schlegel under the name of genera as very natural. He thinks that the system of that author is the best in the present state of science, provided the modifications proposed in 1858 by Dr. Günther, in the 'Catalogue of Ophidia in the British Museum,' be adopted. There are, no doubt, exceptions ; but we find entire families with two pits, others with only one, and others which are destitute of them. Moreover, the families in which all the species exhibit a uniformity of character in this respect are generally very natural families.

M. Reinhardt himself does not ascribe an exaggerated importance to the pits in question. He does not dream of making use of them as the basis of a classification. But it is interesting to find, in a peculiarity apparently so useless, a confirmation of the establishment of certain families; and it may also serve occasionally to determine the probable affinity of an Ophidian whose position is doubtful.Bibl. Univ. Jan. 20, 1862, Bull. Sci. p. 78.

Note on Callithamnion Rothii. By G. S. Brady.

The influence of external circumstances in introducing changes of species, and the range of altered conditions which individual species are qualified to bear without change or death, is a matter which seems as yet to be very imperfectly understood, notwithstanding that it lies near the root of much that has recently been written respecting the succession of life on the earth. Viewed in this light, the following remarks on one of our native Algæ may not be without interest.

In February of last, and June of the present year, I observed that certain stones near the mouth of a cave, a little north of Hawthorne Dene, were covered with a red velvety fleece, which on examination proved to be Callithamnion Rothii, one of the smallest of the Rhodosperms, its filaments seldom much exceeding half an inch in length. The stones thus coated with the Callithamnion were exposed to a heavy dripping of fresh water from the roof of the cave (not merely a scanty fall of drops, few and far between, but a copious pelting, sufficient to wet one very unpleasantly while gathering specimens), and beyond the area of this dripping the plant did not extend. The mouth of the cave is not very far below high-water mark; and I should judge that in this position the plant must be exposed to 
alternations of about four hours' washing with sea-water, and eight hours' with fresh. I have met with no other instance of a Callithamnion growing under exposure to fresh water ; and when C.Rothii is found (as is often the case) on rocks near high-water mark, it is almost always so stunted as to amount to little more than a red film or crust, in which state it constitutes the Byssus purpurea of old authors*. In the Hawthorne locality, however, it attains a size larger than usual even in favourable situations; so that the fresh water cannot be supposed to exercise any prejudicial influence on its growth. Now, it so happens that there is another genus described by algologists (Trentepohlia), which, according to Professor Harvey, differs from Callithamnion in no other respect than its fresh-vater habitat. Indeed, in the first edition of his 'Manual of the British Algæ,' he remarks " that $C$. Daviesii and $T$. pulchella, when the latter is well coloured, are scarcely distinguishable under the microscope." It seems to me that the Hawthorne plant goes a great way to establish Dr. Harvey's view of the identity of the two genera ; for, though exposed for about sixteen hours out of twenty-four to the influence of fresh water, it is certainly referable to the marine species Callithamnion Rothii, and at the same time is undistinguishable, so far as I can gather from figures and written descriptions, from the fresh-water species Trentepohlia pulchella. There is nothing exceptional in the case of a plant growing indifferently either in salt water or in fresh. The common Enteromorpha intestinalis, a marine species, flourishes in streams, ponds, and ditches quite away from sea influence. Bangia fusco-purpurea has been found in like circumstances; and even with animals, instances of a similar tolerance might be brought forward. In short, it seems quite unphilosophical to separate plants which are to all appearance precisely similar, merely on account of a difference in habitat; for what does such a circumstance show, more than that a single species possesses the capacity of existence under widely different conditions?-Trans. Tyneside Naturalists' Field Club, 1861.

\section{Vitality of the Seed of Fumaria muralis (Sonder) and Hyoscyamus niger $(\boldsymbol{L}$. $)$ By the Rev. Alfred Merle Norman, M.A.}

The ancient churchyard of Embleton, in the parish of Sedgefield, was surrounded by a very old hedge, which, last year, when the church was rebuilt, was grubbed up. Upon this freshly turned-up groundearth which had not been disturbed for centuries-there sprung up in profusion two interesting plants, Fumaria muralis (Sonder) and Hyoscyamus niger (L.). What makes the circumstance the more

* Byssus purpurea is noted by Mr. Winch as occurring "on rocks and stones in alpine situations." Assuming that the plant alluded to is the same as that found on rocks with marine exposure (which, though evidently inferred by Mr. Winch, is perhaps reasonably open to doubt), there seems the less reason to hesitate in uniting the two aquatic forms. But, without further evidence of the identity of the two terrestrial plants, it is impossible to push this argument. 


\section{$2 \mathrm{BHL}$ Biodiversity Heritage Library}

Brady, George Stewardson. 1862. "Note on Callithamnion Rothii." The Annals and magazine of natural history; zoology, botany, and geology 9, 256-257.

View This Item Online: https://www.biodiversitylibrary.org/item/87333

Permalink: https://www.biodiversitylibrary.org/partpdf/64609

\section{Holding Institution}

Smithsonian Libraries

\section{Sponsored by}

Smithsonian

\section{Copyright \& Reuse}

Copyright Status: Public domain. The BHL considers that this work is no longer under copyright protection.

This document was created from content at the Biodiversity Heritage Library, the world's largest open access digital library for biodiversity literature and archives. Visit BHL at https://www.biodiversitylibrary.org. 